\title{
Productivity and economic evaluation of Willow (Salix alba L.) based silvopastoral agroforestry system in Kashmir valley
}

\section{G.M. Bhat}

Faculty of Forestry, Sher-e-Kashmir University of Agricultural Sciences and Technology of Kashmir, Benhama, Ganderbal-191201 (J\&K), India

\section{M.A. Islam*}

Faculty of Forestry, Sher-e-Kashmir University of Agricultural Sciences and Technology of Kashmir, Benhama, Ganderbal-191201 (J\&K), India

\section{A.R. Malik}

Faculty of Forestry, Sher-e-Kashmir University of Agricultural Sciences and Technology of Kashmir, Benhama, Ganderbal-191201 (J\&K), India

\section{T.A. Rather}

Faculty of Forestry, Sher-e-Kashmir University of Agricultural Sciences and Technology of Kashmir, Benhama, Ganderbal-191201 (J\&K), India

\section{F.A. Shah Khan}

Faculty of Forestry, Sher-e-Kashmir University of Agricultural Sciences and Technology of Kashmir, Benhama, Ganderbal-191201 (J\&K), India

A.H. Mir

Faculty of Forestry, Sher-e-Kashmir University of Agricultural Sciences and Technology of Kashmir, Benhama, Ganderbal-191201 (J\&K), India

*Corresponding author. E-mail: ajaztata@gmail.com

\begin{abstract}
Performance of two fodder crops namely, sorghum (Sorghum vulgare L.) and maize (Zea mays L.) was investigated with Willow (Salix alba L.) to evaluate productivity and economics of the silvopastoral agroforestry system in Kashmir valley. The experiment was laid out by planting two year old willows at $2.0 \mathrm{~m} \times 2.0 \mathrm{~m}$ spacing and dividing the main plot into sub-plots of size $8 \mathrm{~m} \times 2 \mathrm{~m}$ each with 5 replications in randomized block design (RDB). The intercrops of sorghum and maize were maintained at $20 \mathrm{~cm} \times 10 \mathrm{~cm}$ spacing and supplied with recommended doses of fertilizers. The economics of the willow plantation intercropped with fodder crops was compared with sole willow farming by the benefitcost ratio and net present worth. The study revealed the differential behaviour of Salix alba regarding growth parameters (height, diameter and girth) by different intercrops and various fodder intercrops with respect to yield, above ground biomass, dry matter production and soil nutrient status $\mathrm{pH}$, organic carbon, available nitrogen, phosphorus and potassium). The willow based silvopastoral system was estimated to have benefit-cost ratio of 2.71 with maize and 2.68 with sorghum, while as sole crop the willows accrued a benefit-cost ratio of 2.66. The study is useful in discovering growth of willows, productivity of fodder crops and soil nutrient status under various silvopastoral agroforestry systems for maximizing economic gains. The findings envisaged evidences in favour of adopting willow based silvopastoral agroforestry instead of sole tree farming and the knowledge of interactions will be helpful in proper management of the system for sustained multiple productions.
\end{abstract}

Keywords: Agroforestry, Biomass, Economics, Fodder crops, Silvopastoral, Salix alba, Soil nutrients

\section{INTRODUCTION}

Agroforestry is a sustainable land management system where woody perennials are integrated with agriculture and pastoral operations in farm and rangeland to maximize production, diversify local products and economies, secure food and livelihood security, improve landscape and micro-

\section{Article Info}

https://doi.org/

10.31018/jans.v11i3.2104

Received: May 14, 2019

Revised: September 7, 2019

Accepted: September 9, 2019

\section{How to Cite}

Bhat, G.M. et al. (2019). Productivity and economic evaluation of Willow (Salix alba L.) based silvopastoral agroforestry system in Kashmir valley. Journal of Applied and Natural Science, 11(3): 743- 751 https://doi.org/ 10.31018/jans.v11i3.2104 
2019). The practice of agroforestry is done taking into consideration many benefits it can offer to a farmer in a large or small scale such as (i) financial outcomes including capital investment, increased family income, creating employment opportunities, migration reduction, increased livestock production, supplementary income, decreased farm expenditure, utilization of unproductive lands, enhancement of property values, etc. (ii) environmental outcomes including increase in biomass production, decreased land degradation, groundwater recharge, reduction in dependency on natural forests, reduction in incidence of pest and diseases, climate change mitigation, modification of micro-climate, carbon sequestration, pollution reduction, biodiversity conservation and protection of wildlife habitat, etc. (iii) agricultural outcomes including soil improvement, enhanced production of food grains, providing shade and shelter, weed control, multiple forest products like fuel, fodder, timber and other NTFPs, etc. (iv) cultural outcomes including maintenance of cultural heritage, recreation opportunities, preservation of spirituals, values, beliefs, customary rituals, habits, totems, festivals, taboos, folklore, traditional recipes etc. (Thomas 1990; Nair 1991; Swinkels and Scherr, 1991; Current et al., 1995; Blanc et al., 2019; Hanisch et al., 2019; Musa et al., 2019). These benefits of agroforestry add up to a substantial improvement of the economic and resource sustainability of agriculture (Islam et al., 2015; Quli and Islam, 2017; Yadav et al., 2019). In fact, combining the woody trees and shrubs with agricultural and pastoral operations, the agroforestry ensures sustainable multifunctional integrated production system for generations (Quli et al., 2017; Chará et al., 2019; Jose and Dollinger, 2019). Agroforestry is today even more relevant in the context of growing human and livestock population especially in developing countries like India (Dagar, 2012; Bhat and Islam, 2017). In fact silvoarable agroforestry has recently been proposed as an alternative land-use system for Europe (Reisner et al., 2007). The scope to increase the land area under cultivation to solve the problem of acute shortages of food, fuel wood, fodder, timber and other NTFPs is very limited. Presently, there is huge dearth of fuel wood $(77 \%)$, timber $(55 \%)$, green fodder $(77 \%)$ and dry fodder $(51 \%)$ (Roy, 1999).

Consequently, we require to increase the production from the land already under cultivation by adopting systems which are capable of producing the daily human needs i.e. food, fodder, timber and fuel wood from marginal areas by increasing productivity and also maintaining and improving the quality of environment (Kareemulla et al., 2009). Agroforestry is the only viable alternative which is capable of meeting the present challenges (Islam et al., 2016; Bhaskar et al., 2019). The agroforestry landscape spreads over $20 \%$ of the total geographic region of the Himalayan setting of India and the agroforestry network is distributed in the surroundings of forests covering $52 \%$ area (Anon., 2017). Hence, land development planning in the region needs to be based on an integrated consideration of agroforestry and forestry systems rather than considering the two systems as independent or alternative land uses (Islam et al., 2017a). In general, very few studies are available focussing on agroforestry economic analyses. The reviews (Swinkels and Scherr, 1991) shown that majority of the economic analyses done for any specific agroforestry practices so far have focused mainly on financial profits only. Although a number of studies (Mughal and Bhattacharya, 2000; Mughal and Bhattacharya, 2002; Sood, 2006; Banyal et al., 2011; Islam et al., 2012; Islam et al., 2015; Ahmad et al., 2017; Islam et al., 2017; Maqbool et al., 2017) on Himalayan agroforestry systems exist, but little work has been done in this regard in the Kashmir Himalayan region (Mir and Khan, 2008; Islam et al., 2017b). The aim of this article is to study the interaction of the components of an agroforestry system and to construct the projected economic analysis based on the benefit-cost ratio of the system. Therefore, the present study analysed the projected economic analysis, dry matter production and nutrients status of soil in a silvopastoral agroforestry involving willow (S. alba L.) plantation and fodder crops of sorghum (Sorghum vulgare) and maize (Zea mays L.).

\section{MATERIALS AND METHODS}

The silvopastoral experiment was laid out at farmer's field in randomized block design (RDB) at Shalimar, Srinagar, J\&K, India. The site extends within $34^{\circ} 05^{\prime} \mathrm{N}$ latitude and $74^{\circ} 89^{\prime} \mathrm{E}$ longitude at an altitude of 1560 meters above mean sea level. The two year old willow plants were planted at the beginning of our experiment. The main plot was divided into sub-plots of size $8 \mathrm{~m} \times 2 \mathrm{~m}$ each in which four willow trees were at a spacing of $2 \mathrm{~m} \times$ $2 \mathrm{~m}$. The experiment was laid out with 5 replications. The interspaces maintained under $20 \mathrm{~cm} \times$ $10 \mathrm{~cm}$ spacing were intercropped with sorghum and maize and the fertilizers doses already recommended were applied. The climate is general of typical temperate type; the winters are severe extending from December to March and the temperature goes below freezing point. Most of the precipitation is received from December to April in the form of snow or rain. The summers are moderate with temperatures ranging from $25^{\circ} \mathrm{C}$ to $33^{\circ} \mathrm{C}$ from April to September. The autumn season extends from October to November with temperature between $18{ }^{\circ} \mathrm{C}$ to $25^{\circ} \mathrm{C}$.

The tree height $(\mathrm{m})$ was measured from the ground to the tip of the main shoot with the help of the graduated wooden scale. The girth $(\mathrm{cm})$ of the trees was measured at breast height $(1.37 \mathrm{~m})$ with the help of measuring tape. The diameter $(\mathrm{cm})$ of the trees was measured at breast height using caliper, in both the directions analogous to the axes of the tree bole opposite to each other and 
the average of the two measurements was worked out to obtain diameter with minimum error. The samples of the soil were collected from 0-25 $\mathrm{cm}$ depth using posthole augur, air dried, passed through sieve and analyzed for various chemical characters. The yields were recorded by randomly selecting 25 plots in each treatment and weight on fresh weight basis, which was converted into average yield $(q / h a)$ in terms of usable or edible portion.

The data obtained on the economical analysis were subjected to statistical analysis (Snedecor and Cochran, 1967); the significant effects of the treatments were exhibited by calculating the least significance difference (LSD) at $5 \%$ probability level. Projected benefit-cost ratio of sole tree crop (of same dimensions as that of tree + crop) and combination (tree + crop) was computed by taking the net present benefits as numerator and the net present costs as denominator. Conversely, the net present worth was estimated by the subtraction of the net present benefits with net present costs as described in our previous paper (Mir and Khan, 2008)

$B=N_{1} / N_{2}$

where, $B=$ benefit/cost ratio,

$N_{1}=$ net present benefits, and

$N_{2}=$ net present costs.

$\mathrm{W}=N_{1}-N_{2}$

where, $W=$ net present worth (NPW)

The benefit/cost ratio and the net present worth (NPW) of the agroforestry systems were analysed on per hectare basis. Inputs like fertilizers were given to the fodder crops on per hectare basis as as per the recommendations suggested in the package and practices of the fodder crops (Table 1 ) and the cost of fertilizers were estimated as per the current local market prices of fertilizers. The quantity of planting materials viz., maize seeds, sorghum seeds, two-year old willow seedlings required to be planted at a spacing of $2 m^{\prime} 2 \mathrm{~m}$ in a hectare were first estimated (Table 2), then the costs of these planting materials were calculated as per the local market rate. The labour costs for the agroforestry plantation establishment, maintenance, intercropping, harvesting etc. required during the experimentation and throughout the rotation of willow were calculated as per the local labour rates (Table 3 ). Rapid market survey were conducted to ascertain the sale rate of the agroforestry products namely, grasses, tree fodder, fuel wood and timber for cricket bat clefts etc. (Table 4).

The cash flow was negative in the initial years because the costs invested were more mainly due to land preparation, pit digging, fencing, implements, etc. while the cash flow was positive in the subsequent years because the benefits earned were more due to harvesting of grasses, tree fodder, fuel wood etc. However, the social and environmental benefits accrued from agroforestry systems were not included in the benefit/cost ratio analysis. Basically, the development of agroforestry plantation is a long-gestation enterprise, where huge costs are invested in early years and the financial benefits are generally accrued after many years. Hence, the costs and benefits of agroforestry plantation are calculated in advance considering all the factors at the commencement of the venture (Feldhake et al., 1985; Nair, 1998; Leakey, 2012; Musokwa et al., 2018). It was planned that the harvesting of the agroforestry tree crop will be carried out at the rotation of 16 years and all the products will be marketed in the local market at firsthand purchasers by the farmers. The benefitcost analysis of the agroforestry plantation was computed assuming the rate of return @ 12\%. To ensure best growth and development of the agroforestry plantation, gain better earlier returns from the usufructs and get maximum net timber yield, the pre-commercial thinnings to be practiced were presumed at the age of 8,10 and 12 years. The intercropping of fodder crops viz., sorghum and maize in the interspaces of agroforestry plantations in the succeeding years was assumed till the years when the tree canopy becomes denser and growth and production of the crops is reduced.

Valuation of benefits: Fuel wood: Since fuel wood is sold in village markets, hence, its value was estimated at prevailing market prices.

Tree leaf fodder: It was estimated on the present average market prices for the trees of specific size and age and was sold on weight basis i.e. ₹/ ton.

Timber: The trees left upon rotation age were presumed to have been cut for timber (Cricket bat clefts) and valued as per market prices.

Fodder Crops: The fodder crops (sorghum and maize) were sold as per the prevailing market and the yield of these intercrops in the subsequent years was presumed to have been drastically reduced due to closing of the tree canopy and not taken into consideration.

\section{RESULTS AND DISCUSSION}

Growth of Salix alba as affected by intercrops: The average tree height were; initial, $4.65 \mathrm{~m}$; final, $5.18 \mathrm{~m}$ i.e. $11.40 \%$ increase in height and girth were; initial; $13.92 \mathrm{~cm}$; final, $14.80 \mathrm{~cm}$ i.e. $6.35 \%$ increase in girth under $S$. alba + maize. Similarly, the average height of trees were; initial, $4.00 \mathrm{~m}$; final, $4.42 \mathrm{~m}$ i.e. $10.72 \%$ increase in height and average girth of trees were; initial, $12.66 \mathrm{~cm}$; final, $13.64 \mathrm{~cm}$ i.e. $7.78 \%$ increase in girth for $S$. alba + sorghum. S. alba alone performed average tree heights; initial, $5.0 \mathrm{~m}$; final, $5.70 \mathrm{~m}$ i.e. $14.02 \%$ increase in height and average girths; initial, 14.82 $\mathrm{cm}$; final, $16.02 \mathrm{~cm}$ i.e. $8.06 \%$ increase in girth (Table 5). The growth data for $S$. alba trees as influenced by intercropping of maize and sorghum was recorded for height and girth at two stages i.e. before sowing intercrops and at the end of the growing season. The results indicated that per cent increase in height and girth was recorded largest in S. alba alone. However, significant per cent increase in growth and girth of $S$. alba was also recorded with intercrops. The maximum growth when raised without intercrops (control) 
Bhat, G.M. et al. / J. Appl. \& Nat. Sci. 11(3): 743- 751 (2019)

Table 1. Fertilizer cost for silvopastoral agroforestry plantation.

\begin{tabular}{llllllll}
\hline Variable & \multicolumn{3}{c}{ Quantity $\left(\mathrm{Kg} \mathrm{ha}^{-1}\right)$} & \multicolumn{2}{c}{ Rate (₹) ${ }^{*}$} & Total Amount (₹) $^{*}$ \\
\cline { 2 - 7 } & Urea & DAP & MOP & Urea & DAP & MOP & \\
\hline Sorghum & 190 & 110 & 64 & 1140 & 1375 & 384 & 2899 \\
Maize & 171 & 132 & 32 & 1026 & 1650 & 192 & 2868 \\
\hline
\end{tabular}

*@ ₹ 600, 1250 and 600 for one quintal each of urea, DAP and MOP respectively

Table 2. Cost of planting materials for silvopastoral agroforestry plantation.

\begin{tabular}{llll}
\hline Variable & Quantity & Rate (₹) & Amount (₹) \\
\hline Willow trees (Seedling) & 2500 & 10 & 25000 \\
Sorghum $(\mathrm{kg})$ & $30 \mathrm{~kg}$ & 30 & 900 \\
Maize $(\mathrm{kg})$ & $50 \mathrm{~kg}$ & 10 & 500 \\
\hline
\end{tabular}

Table 3. Labour costs for silvopastoral agroforestry plantation.

\begin{tabular}{lccccccc}
\hline Variable & \multicolumn{7}{c}{ Yearl Amount (₹) $^{*}$} \\
\cline { 2 - 8 } & $\mathbf{1}$ & $\mathbf{2}$ & $\mathbf{3}$ & $\mathbf{4}$ & $\mathbf{5}$ & $\mathbf{6 - 1 5}$ & $\mathbf{1 6}$ \\
\hline Willow & 11620 & 3500 & 7000 & 10500 & 14000 & 358320 & 5040 \\
Sorghum & 18000 & 16000 & 7000 & 10500 & 14000 & 358320 & 5040 \\
Maize & 18000 & 16000 & 7000 & 10500 & 14000 & 358320 & 5040 \\
\hline
\end{tabular}

Table 4. Market prices of agricultural and tree produces of silvopastoral agroforestry plantation.

\begin{tabular}{ll}
\hline Item & Price (₹) \\
\hline Sorghum (ton) & 3000 \\
Maize (Fodder) (ton) & 2500 \\
Fuel wood (ton) & 3000 \\
Tree fodder (ton) & 750 \\
Timber (Cricket bat clefts) & 100 \\
\hline
\end{tabular}

was obviously due to absence of any competition for growth resources (Ahmad et al., 2017; Bhaskar et al., 2019). The tree growth information provided an indication of better production values per unit area under agroforestry which is in consistent with the previous workers (Anusha et al., 2015; Blanc et al., 2019; Brown et al., 2018).

Yield of intercrops as affected by Salix alba: The fodder crop's average yield was; 199.60 q/ha;
$35.68 \%$ reduction in yield over control under $S$. alba + maize. Similarly, the average yield of agricultural crops was $156.55 \mathrm{q} / \mathrm{ha} ; 48.69 \%$ reduction in yield over control for $S$. alba + sorghum. The average yield of maize alone was $310 \mathrm{q} / \mathrm{ha}$ and the average yield of sorghum alone was $305.12 \mathrm{q} /$ ha (Table 5). The yield was considerably higher when agricultural crops were grown as sole crops than the crops grown as intercrops with $S$. alba. While comparing the yield of sole crops with their corresponding intercrops, highest reduction in yield was recorded in $S$. alba + sorghum followed by $S$. alba + maize. The reduction in yield of intercrops grown in association with $S$. alba reflected the competition for growth resources such as, moisture, nutrients, and radiant energy (Feldhake et al., 2008; Dar et al., 2018). The reduction in the yield of intercrops with $S$. alba as compared to

Table 5. Tree height, girth, crop yield, yield reduction and crop dry weight under willow (Salix alba L.) based silvopastoral agroforestry system.

\begin{tabular}{|c|c|c|c|c|c|c|c|c|c|c|c|}
\hline \multirow[t]{2}{*}{ Treatment } & \multicolumn{3}{|c|}{ Tree height (m) } & \multicolumn{3}{|c|}{ Tree girth $(\mathrm{cm})$} & \multirow{2}{*}{$\begin{array}{l}\text { Crop } \\
\text { yield } \\
\text { (q/ha) }\end{array}$} & \multirow{2}{*}{$\begin{array}{l}\text { Yield } \\
\text { reduc- } \\
\text { tion (\%) }\end{array}$} & \multicolumn{3}{|c|}{ Dry weight (q/ha) } \\
\hline & Initial & Final & $\begin{array}{l}\text { Increase } \\
(\%)\end{array}$ & Initial & Final & $\begin{array}{l}\text { Increase } \\
(\%)\end{array}$ & & & $\begin{array}{l}35 \\
\text { days }\end{array}$ & $\begin{array}{l}70 \\
\text { days }\end{array}$ & $\begin{array}{l}105 \\
\text { days }\end{array}$ \\
\hline $\begin{array}{l}\text { S. alba + } \\
\text { maize }\end{array}$ & 4.65 & 5.18 & 11.40 & 13.92 & 14.80 & 6.35 & 199.60 & 35.68 & 0.42 & 6.58 & 18.70 \\
\hline $\begin{array}{l}\text { S. alba + } \\
\text { sorghum }\end{array}$ & 4.00 & 4.42 & 10.72 & 12.66 & 13.64 & 7.78 & 156.55 & 48.69 & 0.18 & 4.23 & 14.97 \\
\hline $\begin{array}{l}\text { S. alba } \\
\text { alone }\end{array}$ & 5.00 & 5.70 & 14.02 & 14.82 & 16.02 & 8.06 & - & - & - & - & - \\
\hline Maize & - & - & - & - & - & - & 310.37 & - & 1.70 & 16.76 & 30.35 \\
\hline Sorghum & - & - & - & - & - & - & 305.12 & - & 1.40 & 14.01 & 28.91 \\
\hline
\end{tabular}

Table 6. Nutrient status of soil before and after sowing of crops under willow (Salix alba L.) based silvopastoral agroforestry system.

\begin{tabular}{|c|c|c|c|c|c|c|c|c|c|c|c|}
\hline \multirow[t]{3}{*}{ Treatment } & & \multirow{2}{*}{\multicolumn{5}{|c|}{ Before sowing }} & \multirow{2}{*}{\multicolumn{5}{|c|}{ After sowing }} \\
\hline & & & & & & & & & & & \\
\hline & & $\mathrm{pH}$ & $\begin{array}{l}\text { Organ- } \\
\text { ic car- } \\
\text { bon (\%) }\end{array}$ & $\begin{array}{c}\text { Avalla- } \\
\text { ble nitro- } \\
\text { gen (kg/ } \\
\text { ha) }\end{array}$ & $\begin{array}{l}\text { Avallable } \\
\text { phosphorus } \\
\text { (kg/ha) }\end{array}$ & $\begin{array}{c}\text { Avallable } \\
\text { potassium } \\
\text { (kg/ha) }\end{array}$ & $\mathrm{pH}$ & $\begin{array}{l}\text { Urganic } \\
\text { carbon } \\
(\%)\end{array}$ & $\begin{array}{c}\text { Avalla- } \\
\text { ble nitro- } \\
\text { gen (kg/ } \\
\text { ha) }\end{array}$ & $\begin{array}{l}\text { Avallable } \\
\text { phospho- } \\
\text { rus (kg/ha) }\end{array}$ & $\begin{array}{c}\text { Avallable } \\
\text { potassi- } \\
\text { um (kg/ } \\
\text { ha) }\end{array}$ \\
\hline $\begin{array}{l}S . \quad \text { alba } \\
\text { maize }\end{array}$ & + & 6.35 & 0.94 & 304.08 & 17.66 & 260.50 & 6.27 & 0.99 & 306.00 & 18.00 & 274.54 \\
\hline $\begin{array}{l}\text { S. alba } \\
\text { sorghum }\end{array}$ & + & 6.40 & 0.91 & 295.00 & 19.50 & 302.40 & 6.23 & 0.97 & 297.31 & 20.00 & 310.28 \\
\hline Maize & & 6.61 & 0.73 & 277.37 & 15.73 & 266.20 & 6.29 & 0.75 & 277.50 & 15.80 & 265.90 \\
\hline Sorghum & & 6.67 & 0.79 & 279.00 & 16.06 & 228.80 & 6.60 & 0.80 & 279.30 & 16.25 & 230.10 \\
\hline
\end{tabular}


Bhat, G.M. et al. / J. Appl. \& Nat. Sci. 11(3): 743- 751 (2019)

Table 7. Net present worth (NPW) and benefit-cost (BC) of Salix alba + Maize based silvipastoral agroforestry plantation (₹/ha).

\begin{tabular}{|c|c|c|c|c|c|c|c|c|}
\hline \multirow{2}{*}{ Particular } & \multicolumn{8}{|c|}{ Year } \\
\hline & $1^{\mathrm{st}}$ & $2^{\text {nd }}$ & $3^{\text {rd }}$ & $4^{\text {th }}$ & $5^{\text {th }}$ & $6^{\text {th }}-15^{\text {th }}$ & $16^{\text {th }}$ & Total \\
\hline $\begin{array}{l}\text { Costs: } \\
\text { Depreciation on fixed cost } \\
(₹ 56000) @ 10 \% \text { \& land } \\
\text { rental }\end{array}$ & 23600 & 23040 & 22536 & 22082 & 21674 & 201537 & 19153 & 333622 \\
\hline $\begin{array}{l}\text { Plantation \& harvesting } \\
\text { costs (Tree) }\end{array}$ & 38420 & 5300 & 8800 & 12300 & 15800 & 376320 & 156840 & 613780 \\
\hline $\begin{array}{l}\text { Cultivation \& harvesting } \\
\text { costs (Maize) }\end{array}$ & 22436 & 20336 & -- & -- & -- & -- & -- & 42772 \\
\hline Interest* & 5244 & 1538 & 2049 & 2228 & 2411 & 36183 & 10703 & 61911 \\
\hline $\begin{array}{l}\text { Total cost } \\
\text { Benefits: }\end{array}$ & 89700 & 50214 & 33385 & 36610 & 39885 & 614040 & 186696 & 1052085 \\
\hline Fuel wood \& fodder & -- & 15000 & 30000 & 45000 & 60000 & 2669400 & 21600 & 2841000 \\
\hline Timber (Cricket bat clefts) & -- & -- & -- & -- & -- & - & 900000 & 900000 \\
\hline Maize & 49900 & 15517 & -- & -- & -- & -- & -- & 65417 \\
\hline Total benefits & 49900 & 30517 & 30000 & 45000 & 60000 & 2669400 & 921600 & 3806417 \\
\hline $\begin{array}{l}\text { Discounted costs @ 12\% } \\
\text { pa. }\end{array}$ & 89700 & 44690 & 26374 & 25993 & 25128 & 206932 & 29871 & 448688 \\
\hline $\begin{array}{l}\text { Discounted benefits @ } \\
12 \% \text { pa. }\end{array}$ & 49900 & 27160 & 23700 & 31950 & 37800 & 899586 & 147456 & 1217552 \\
\hline
\end{tabular}

NPW= $₹ 1217552-₹ 448688=₹ 768864 ; B / C$ ratio $=₹ 1217552 / ₹ 448688=2.71$, Fixed cost include costs of fencing, irrigation, repairs, implements etc.; Plantation/Cultivation costs include costs of planting material, seed, fertilizer, labour etc. and 5\% miscellaneous charges. ${ }^{*}$ Represents interest on fixed cost @ 6.75\% and on variable cost @ 6\%.

Table 8. Net present worth (NPW) and benefit-cost (BC) of Salix alba + Sorghum based silvipastoral agroforestry plantation (₹/ha).

\begin{tabular}{|c|c|c|c|c|c|c|c|c|}
\hline \multirow{2}{*}{ Particular } & \multicolumn{8}{|c|}{ Year } \\
\hline & $1^{\text {st }}$ & $2^{\text {nd }}$ & $3^{\text {rd }}$ & $4^{\text {th }}$ & $5^{\text {th }}$ & $6^{\text {th }}-15^{\text {th }}$ & $16^{\text {th }}$ & Total \\
\hline \multirow{4}{*}{$\begin{array}{ll}\text { Costs: } & \\
\text { Depreciation on fixed cost (₹ } \\
56000) @ 10 \% \text { \& land rental } \\
\text { Plantation \& } & \text { harvesting } \\
\text { costs (Tree) } & \\
\text { Cultivation \& } & \text { harvesting } \\
\text { costs (Sorghum) }\end{array}$} & 23600 & 23040 & 22536 & 22082 & 21674 & 201537 & 19153 & 333622 \\
\hline & 38420 & 5300 & 8800 & 12300 & 15800 & 376320 & 156840 & 613780 \\
\hline & 22831 & 20731 & -- & -- & -- & -- & -- & 43562 \\
\hline & 5268 & 1562 & 2049 & 2228 & 2411 & 36183 & 10703 & 60404 \\
\hline $\begin{array}{l}\text { Total cost } \\
\text { Benefits: }\end{array}$ & 90119 & 50633 & 33385 & 36610 & 39885 & 614040 & 186696 & 1051368 \\
\hline Fuel wood \& fodder & -- & 15000 & 30000 & 45000 & 60000 & 2669400 & 21600 & 2841000 \\
\hline Timber (Cricket bat clefts) & -- & -- & -- & -- & -- & -- & 900000 & 900000 \\
\hline Sorghum & 46965 & 9150 & -- & -- & -- & -- & -- & 46762 \\
\hline Total benefits & 39137 & 24150 & 30000 & 45000 & 60000 & 2669400 & 921600 & 3787762 \\
\hline $\begin{array}{l}\text { Discounted costs @ 12\% } \\
\text { pa. }\end{array}$ & 90119 & 45063 & 26374 & 25993 & 25128 & 206932 & 29871 & 449480 \\
\hline $\begin{array}{l}\text { Discounted benefits @ 12\% } \\
\text { pa. }\end{array}$ & 46965 & 21493 & 23700 & 31950 & 37800 & 899586 & 147456 & 1208950 \\
\hline
\end{tabular}

NPW= $₹ 1208950-₹ 449480=₹ 759470 ; B / C$ ratio $=₹ 1208950 / ₹ 449480=2.68$, Fixed costs include costs of fencing, irrigation, repairs, implements etc., Plantation/Cultivation costs include costs of planting material, seed, fertilizer, labour etc. and 5\% miscellaneous charges., * Represents interest on fixed cost @ 6.75\% and on variable cost @ 6\%.

their sole crops can be explained as per observations of (Ong et al., 1996; Jose and Dollinger, 2019), who stated that the main source of radiation in understory crop is diffuse radiation which has previously been intercepted and transmitted. This process is known to deplete significant amount of photo-synthetically active radiation (PAR) before it reaches understory crop (Edje, 2014; Musokwa et al., 2018).

Dry matter production of intercrops as affected by Salix alba: The dry matter production of intercrop were; after 30 days (0.42 q/ha), after 70 
Bhat, G.M. et al. / J. Appl. \& Nat. Sci. 11(3): 743- 751 (2019)

Table 9. Net present worth (NPW) and benefit-cost (BC) of Salix alba plantation (₹/ha).

\begin{tabular}{|c|c|c|c|c|c|c|c|c|}
\hline \multirow{2}{*}{ Particular } & \multicolumn{8}{|c|}{ Year } \\
\hline & $1^{\text {st }}$ & $2^{\text {nd }}$ & $3^{\text {rd }}$ & $4^{\mathrm{th}}$ & $5^{\text {th }}$ & $6^{\text {th }}-15^{\text {th }}$ & $16^{\text {th }}$ & Total \\
\hline \multirow{3}{*}{$\begin{array}{l}\text { Costs: } \\
\text { Depreciation on fixed cost (₹ } \\
56000) @ 10 \% \text { \& land rental } \\
\text { Plantation \& harvesting } \\
\text { costs (Tree) } \\
\text { Interest* }\end{array}$} & 23600 & 23040 & 22536 & 22082 & 21674 & 201537 & 19153 & 333622 \\
\hline & 38420 & 5300 & 8800 & 12300 & 15800 & 376320 & 156840 & 613780 \\
\hline & 3898 & 1873 & 2049 & 2228 & 2411 & 36183 & 10703 & 59345 \\
\hline $\begin{array}{l}\text { Total cost } \\
\text { Benefits: }\end{array}$ & 65918 & 30213 & 33385 & 36610 & 39885 & 614040 & 186696 & 1006747 \\
\hline Fuel wood \& fodder & -- & 15000 & 30000 & 45000 & 60000 & 2669400 & 21600 & 2841000 \\
\hline Timber (Cricket bat clefts) & -- & -- & -- & -- & -- & -- & 900000 & 900000 \\
\hline Total benefits & -- & 15000 & 30000 & 45000 & 60000 & 2669400 & 921600 & 3741000 \\
\hline $\begin{array}{l}\text { Discounted costs @ 12\% } \\
\text { pa. }\end{array}$ & 65918 & 26889 & 26374 & 25993 & 25128 & 206932 & 29871 & 433479 \\
\hline $\begin{array}{l}\text { Discounted benefits @ 12\% } \\
\text { pa. }\end{array}$ & -- & 13350 & 23700 & 31950 & 37800 & 899586 & 147456 & 1153842 \\
\hline
\end{tabular}

NPW $=₹ 1153842-₹ 433479=₹ 720363 ; B / C$ ratio $=₹ 1153842 / ₹ 433479=2.66$; Fixed costs include costs of fencing, irrigation, repairs, implements etc.; Plantation cost includes costs of planting material, fertilizer, labour etc. and 5\% miscellaneous charges; " ${ }^{*}$ Represents interest on fixed cost @ 6.75\% and on variable cost @ 6\%.

days (6.58 q/ha) and after 105 days (18.70 q/ha) under $S$. alba + maize. Similarly, the dry matter production of intercrop were; after 30 days $(0.18$ $\mathrm{q} / \mathrm{ha})$, after 70 days (4.23 $\mathrm{q} / \mathrm{ha}$ ) and after 105 days (14.97 q/ha) for $S$. alba + sorghum. The dry matter production of maize alone was recorded as follows; after 30 days $(1.70 \mathrm{q} / \mathrm{ha})$, after 70 days (16.76 q/ha) and after 105 days (30.35 q/ha). The dry matter production of sorghum alone was recorded as follows; after 30 days (1.40 q/ha), after 70 days $(14.01 \mathrm{q} / \mathrm{ha})$ and after 105 days $(28.91 \mathrm{q} /$ ha) (Table 5). Dry matter production of agricultural crops was recorded at three different stages at an interval of 35 days from the date of sowing. The results showed significant differences in dry matter production at all three stages, when intercrops are compared with their corresponding sole crops. It was observed that the variation of dry matter production between sole crop and their respective intercrops reduced as these crops advanced to maturity. This may be attributed to the fact that in the agroforestry system the crops were not able to utilize resources (light, nutrients, moisture) efficiently (Schaffer et al., 2019; Yadav et al., 2019). Here, the diffuse radiations have previously been intercepted and transmitted, perhaps several times by the foliage of the tree. Therefore, this process depletes a significant amount of photosynthetically active light (PAL) before it reaches the understory crop (Bhaskar et al., 2019; Chará et al., 2019) and this interception of PAL may be responsible for decrease in the photosynthetic production in crops grown as intercrops (Brown et al., 2018; Hanisch et al., 2019) and consequently decrease in dry matter production was observed.

Nutrient status of soil: Before sowing the nutrient status of soil was recorded as; $\mathrm{pH}$ (6.35), organic carbon (0.94), available nitrogen $(304.08 \mathrm{~kg} /$ ha), available phosphorus (17.66 kg/ha), available potassium $(260.50 \mathrm{~kg} / \mathrm{ha})$ under $S$. alba + maize. Similarly, the nutrient status of soil was found to be; $\mathrm{pH}$ (6.40), organic carbon (0.91), available nitrogen (295.00 kg/ha), available phosphorus $(19.50 \mathrm{~kg} / \mathrm{ha})$, available potassium $(302.40 \mathrm{~kg} / \mathrm{ha})$ for $S$. alba + sorghum. The soil nutrient status for maize only was; $\mathrm{pH}(6.61)$, organic carbon (0.73), available nitrogen $(277.37 \mathrm{~kg} / \mathrm{ha})$, available phosphorus (15.73 kg/ha), available potassium (266.20 $\mathrm{kg} / \mathrm{ha}$ ). The soil nutrient status for sorghum only was; $\mathrm{pH}$ (6.67), organic carbon (0.79), available nitrogen (279.00 kg/ha), available phosphorus (16.06 kg/ha), available potassium (228.80 kg/ha). After sowing the nutrient status of soil was recorded as; $\mathrm{pH}$ (6.27), organic carbon (0.99), available nitrogen $(306.00 \mathrm{~kg} / \mathrm{ha})$, available phosphorus $(18.00 \mathrm{~kg} / \mathrm{ha})$, available potassium $(274.54 \mathrm{~kg} / \mathrm{ha})$ under S. alba + maize. Similarly, the nutrient status of soil was found to be; $\mathrm{pH}$ (6.23), organic carbon (0.97), available nitrogen (297.31 kg/ha), available phosphorus $(20.00 \mathrm{~kg} / \mathrm{ha})$, available potassium $(310.28 \mathrm{~kg} / \mathrm{ha})$ for $S$. alba + sorghum. The soil nutrient status for maize only was; $\mathrm{pH}$ (6.29), organic carbon (0.75), available nitrogen (277.50 $\mathrm{kg} / \mathrm{ha}$ ), available phosphorus (15.80 kg/ha), available potassium $(265.90 \mathrm{~kg} / \mathrm{ha})$. The soil nutrient status for sorghum only was; $\mathrm{pH}$ (6.60), organic carbon $(0.80)$, available nitrogen $(279.30 \mathrm{~kg} / \mathrm{ha})$, available phosphorus ( $16.25 \mathrm{~kg} / \mathrm{ha})$, available potassium (230.10 kg/ha) (Table 6).

Soil samples for analysis of $\mathrm{pH}$, organic carbon and available NPK were collected from each of the five replications among treatments before the layout of the experiment and also after the end of the growing season and analyzed as per standard procedure. It was observed that initially the soil reaction was slightly acidic and available NPK and organic carbon was observed to be in the medium range. From these examinations, it was assumed 
that the soil was fit for cultivation of agricultural crops. Analysis of soil after harvesting the intercrops, it was observed that $\mathrm{pH}$ of the soil decreased slightly. This decrease in $\mathrm{pH}$ after harvesting the intercrops as compared to initial $\mathrm{pH}$ can be attributed to greater uptake of cation nutrients by the tree and crops and resultant excretion of $\mathrm{H}^{+}$ions into the soil (Maqbool et al., 2017). Also lowering of $\mathrm{pH}$ can be explained on the basis that organic acids were produced during the decomposition of organic matter (Dar et al., 2018). Lowering of $\mathrm{pH}$ in agroforestry system was also reported by Parthiban and Rai (1994).

Furthermore, organic carbon per cent showed increase after the harvest of the crops as compared to nutrient status before layout of experiment. The increase in organic carbon per cent can be explained from the fact that the major avenue for addition of organic matter to the soil is through litter-fall and increase in organic carbon after harvesting can be attributed to decomposed roots, fallen leaves (Fettweis et al., 2005; Musokwa et al., 2018). The soil samples after harvesting showed the increased amount of available NPK in comparison to initially analyzed samples. The increase in nitrogen content and available phosphorus may be attributed primarily to its restitution to soil through fall (Bhaskar et al., 2019). The available phosphorus might also have increased due to organic acids released during microbial decomposition of organic matter enhancing thereby solubility of native phosphates and increase in available phosphorus (Anusha et al., 2015). The increase in available potassium may also be attributed to litter fall (Edje, 2014).

Economic analysis: The results (Tables 7-9) on the projected benefit/cost ratio, depicted that there is considerable enhancement in the financial profits by raising sorghum and maize (fodder crops) in combination with willow trees in agroforestry compared with sole willow plantation. The NPW of sorghum, maize and willow (as sole crops) were ₹ 759470 , ₹ 768864 and $₹ 720363$ per hectare, respectively. The projected benefit-cost ratio analysis indicated that the silvopastoral agroforestry plantation of willow + sorghum and willow + maize generated a benefit/cost (BC) ratio of 2.68 and 2.71 respectively, while the sole willow plantation accrued a BC ratio of 2.66. The silvopastoral practice is one of the most benefiting practices of agroforestry in terms of economic returns and environmental benefits (Chará et al., 2019; Hanisch et al., 2019; Jose and Dollinger, 2019). The cost components in the silvopastoral experiment were land preparation, pit digging, planting material, fencing for the experimental area, fertilizers, labour for planting, inter-culture harvesting and land rental etc. The items of return include fodder crops (sorghum and maize), fuel wood, tree leaf fodder and timber (cricket bat clefts). The study (Mir and Khan, 2008) with willow intercropping with some vegetable crops, it was observed that intercropping also generated higher $\mathrm{BC}$ ratio. The results are encouraging and support the fact that there is an increase in the levels of farm income while adopting agroforestry system as stated by earlier workers (Jain et al., 1999; Bhaskar et al., 2019; Blanc et al., 2019). Karemulla et al. (2002) has reported a higher gross as well as net return from silvopastoral system over single crop which is in line with the present results. The earlier studies (Reddy and Korwar, 1985; Pathak, 1991; Yadav et al., 2019) on evaluation of comparative economics of silvopastoral agroforestry systems under dry land conditions used the similar methods and results were in consistent with the present findings of silvopastoral plantation. The results of this study provided circumstantial evidence in favour of adopting agroforestry over sole forestry (Ahmad et al., 2017; Musa et al., 2019).

\section{Conclusion}

The study demonstrated that the interaction of plant species (tree + crop) showed significant influence of one component of a system on the performance of the other component as well as a whole system. Agroforestry increases the farm income in a number of ways like, the total productivity per unit area through tree/crop association is more than any sole component only and the new products add to the financial diversity and flexibility of the farming enterprise. In the present circumstances, depletion of grazing fields in forests and increase in the livestock production emphasize an escalating necessity for sustainable landmanagement systems, able to fast transformation in socio-economic and ecological situations and simultaneously, sustaining our natural forests. The present study showed that fodder crops like maize and sorghum are compatible with the willow farming. The economics revealed that maize grown as intercrop with willow generates a return of 2.71 followed by sorghum 2.68. The benefit cost ratio of mono-cropping 2.66 being comparatively much lesser therefore strongly favours the adoption agroforestry practices instead of sole farming. This practice has several indirect benefits especially enriching soil, improving microclimate and storing carbon.

\section{ACKNOWLEDGEMENTS}

This research was conducted under the aegis of Faculty of Forestry, SKUAST-K Shalimar, which is gratefully acknowledged. Sincere thanks are due to SKUAST-K for the assistance to carry out this work. The authors thank the farmer for providing his land during the course of this study.

\section{REFERENCES}

1. Ahmad, S., Khan, P.A., Verma, D.K., Mir, N., Singh, J.P., Dev, I. and Roshetko, J.M. (2017). Scope and potential of hortipastoral systems for enhancing livestock productivity in Jammu and Kashmir. Indian Journal of Agroforestry, 19(1):48-56.

2. Anon., (2017). India State of Forest Report (ISFR). Forest Survey of India, Dehradun, Uttarakhand. 3. Anusha, S., Nagaraju, Mallikarjuna, G.B., Bhaskar, 
V., Gururajkombali and Vishwanath, B.R. (2015). Performance of finger millet (Eleusine coracana (L.) Gaertn) in association with different MPTs in agroforestry system. Indian J. of Agroforestry, 17(2): 82-85.

4. Banyal, R., Masoodi, N.A., Masoodi, T.H., Sharma, L.K. and Gangoo, S.A. (2011). Knowledge and attitude of farmers towards agroforestry practices in north Kashmir- a case study. The Indian Forester, 137(12):1377-1381.

5. Bhaskar, V., Hanumanthappa, D.C., Bhavya, V., Nagaraju and Somashekar, K.S. (2019). Growth, yield and economics of finger millet (Eleusine coracana) in Melia dubia based agroforestry system. International Journal of Current Microbiology and Applied Sciences, 8(5): 1945-1950.

6. Bhat, G.M. and Islam, M.A. (2017). Agroforestry need of hour and methodology for calculation of amount of $\mathrm{CO}_{2}$ sequestered by different agroforestry tree species on yearly basis. Integrative Module for Mulberry Based Farming System, pp. 73-79.

7. Blanc, S., Gasol, C.M., Martínez-Blanco, J., Muñoz, P., Coello, J., Casals, P., Mosso, A. and Brun, F. (2019). Economic profitability of agroforestry in nitrate vulnerable zones in Catalonia (NE Spain). Spanish Journal of Agricultural Research, 17(1):1-16

8. Brown, S.E., Miller, D.C., Ordonez, P.J. and Baylis, K. (2018). Evidence for the impacts of agroforestry on agricultural productivity, ecosystem services, and human well-being in high-income countries: a systematic map protocol. Environmental Evidence, 2018: 7-24.

9. Chará, J., Reyes, E., Peri, P., Otte, J., Arce, E. and Schneider, F. (2019). Silvopastoral Systems and their Contribution to Improved Resource Use and Sustainable Development Goals: Evidence from Latin America. FAO, CIPAV and Agri Benchmark, Cali, $60 \mathrm{pp}$.

10.Current, D., Lutz, E. and Scherr, S.J. (1995). The costs and benefits of agroforestry to farmers. The World Bank Research Observer, 10(2): 151- 180.

11.Dagar, J.C. (2012). Utilization of degraded lands/ habitats and poor quality water for livelihood security and mitigating climate change. Indian $\mathrm{J}$. of Agroforestry, 14(1): 1-16.

12.Dar, M., Qaisar, K.N., Ahmad, S. and Wani, A.A. (2018). Inventory and Composition of Prevalent Agroforestry Systems of Kashmir Himalaya. Advances in Research, 14(1): 1-9.

13.Edje, O.T. (2014). Effects of intercropping maize [Zea mays L.] with pigeon pea [Cajanus cajan L.] on seed yield, litter and fuelwood in Middleveld, Swaziland. African Journal of Applied Agricultural Sciences and Technologies 1(2): 1-8.

14.Feldhake, C.M., Belesky, D.P., Mathias, E.L. (2008). Forage production under and adjacent to Robinia pseudoacacia in Central Appalachia, West Virginia. Advances in Agroforestry, 4(1):55-66.

15.Fettweis, U., Bens, O. and Hüttl, R.F. (2005). Accumulation and properties of soil organic carbon at reclaimed sites in the Lusatian lignite mining district afforested with Pinus spp. Geoderma, 129(1-2):81-91

16. Hanisch, A.L., Negrelle, R.R.B., Bonatto, R.A., Nimmo, E.R. and Lacerda, A.E.B. (2019). Evaluating Sustainability in Traditional Silvopastoral Systems (caívas): Looking Beyond the Impact of Animals on Biodiversity. Sustainability, 2019(11), 3098; doi:10.3390/su11113098.

17.Islam, M.A., Banyal, R., Rai, R. and Singh, P.K. (2012). Determinant factors of agroforestry adoption in north Kashmir. Indian Journal of Social Research, 53(2):123-129.
18.Islam, M.A., Masoodi, T.H., Gangoo, S.A., Sofi, P.A. Bhat, G.M., Wani, A.A., Gatoo, A.A., Singh, A. and Malik, A.R. (2015). Perceptions, attitudes and preferences in agroforestry among rural societies of Kashmir, India. Journal of Applied and Natural Science, 7 (2): $976-983$.

19.Islam, M.A., Qaisar, K.N. and Bhat, G.M. (2017a). Indigenous knowledge in traditional agroforestry systems of Kashmir valley: current challenges and future opportunities. International Journal of Forestry and Crop Improvement, 8(1): 68-77.

20.Islam, M.A., Sofi, P.A., Bhat, G.M., Wani, A.A., Gatoo, A.A. Singh, A. and Malik, A.R. (2017b). Public assessment for socioeconomic and environmental services of agroforestry networks in Kashmir Himalaya, India. International Journal of Current Microbiology and Applied Sciences, 6(10: 410-420.

21.Islam, M.A., Sofi, P.A., Bhat, G.M., Wani, A.A., Gatoo, A.A., Singh, A. and Malik, A.R. (2016). Prediction of agroforestry adoption among farming communities of Kashmir valley, India: a logistic regression approach. Journal of Applied and Natural Science, 8(4): 2133-2140

22.Jain, S.K. and Singh, P. (1999). Performance of intercrops in agroforestry systems. The case study of poplar (Populus deltoides) in Uttar Pradesh (India). Indian Forester, 12(2): 195-205.

23.Jose, S. and Dollinger, J. (2019). Silvopasture: a sustainable livestock production system. Agroforestry Systems, 93(1): 1-9.

24.Kareemulla, K., Rai, P., Rao, G.R. and Solanki, K.R. (2002). Economic analysis of silvopastoral system for degraded landed under rain fed conditions. Indian Forester, 128(12): 1346-1350.

25.Kareemulla, K., Rizvi, R.H., Yadav, R.S., Munnaram and S.K. Dhyani. (2009). Agroforestry for rural development - co-operatives as viable institutions. Agricult. Situ. India., May, 2009, pp. 61-67.

26.Leakey, R. (1996). Definition of agroforestry revisited. In: Agroforestry today, vol. 8 no: 1.

27.Leakey, R.B. (2012). Multifunctional agriculture and opportunities for Agroforestry: Implications of IAASTD. Advances in Agroforestry, 9(1):203-214.

28.Maqbool, M., Rasool, R. and Ramzan, S. (2017). Soil physico-chemical properties as impacted by different land use systems in district Ganderbal, Jammu and Kashmir: India. International Journal of Chemical Studies. 5(4):832-840.

29.Mir, A.H., Khan, M.A. (2008). Projected benefit-cost analysis of agri-silvicultural system: vegetable crops intercropping with Salix alba (Willow). Journal of Forestry Research, 19(4):335-339.

30.Moula, E.L. (2005). The economics of tropical agroforestry systems: the case of agroforestry farms in Cameroon. Forest Policy and Economics, 7:199-211

31.Mughal, A.H. and Bhattacharya, P.K. (2002). Agroforestry Systems Practiced in Kashmir Valley of Jammu and Kashmir. The Indian Forester, 128(8):846852.

32.Mughal, A.H., Ara, T. and Bhattacharya, P.K. (2000). Socioeconomic aspects of agroforestry in rural Srinagar of Kashmir valley. The Indian Forester, 126 (3):234-240.

33.Musa, F., Lile, N.A. and Hamdan, D.D.M. (2019). Agroforestry practices contribution towards socioeconomics: a case study of Tawau communities in Malaysia. Agriculture and Forestry, 65(1): 65-72.

34.Musokwa, M., Mafongoya, P. and Lorentz, S. (2018). Evaluation of agroforestry systems for maize (Zeamays) productivity in South Africa. South African Journal of Plant and Soil, DOI: 
10.1080/02571862.2018.1459898.

35.Nair, P.K.R. (1991). State of the art of agroforestry systems. Forest Ecology and Management, 45: 5-29

36.Nair, P.K.R. (1998). Directions in tropical agroforestry research: past, present, and future. Agroforestry Systems, 38(1): 223-245.

37.Nautiyal, S., Maikhuri R.K., Semwal, R.L., Rao, K.S. and Saxena K.G. (1998). Agroforestry systems in the rural landscape - a case study in Garhwal Himalaya, India. Agroforestry Systems, 41: 151-165.

38.Ong, C.K., Black, C.R., Marshall, F.M. and Corlett, J.E. (1996). Principles of resource capture and utilization of light and water: in Tree Crop Interactions A Physiological Approach [Eds. C.K. Ong and P. Huxley]. CAB International, Wallingford, U.K., pp. 73158

39.Parthiba, K.T. and Rai, R.S.V. (1994). Trees on Farmlands-their effects on soil fertility. Annals of Forestry, 2(1): 44-51.

40.Pathak, P.S. (1991). Economic analysis of silvopastoral system. Colloquium on Forestry Economics Research in Asia. Bangkok, Thailand (PRC): Faculty of Forestry, Kassetsart University, pp. 1-150.

41.Quli, S.M.S. and Islam, M.A. (2017). The chronology of genesis and development of agroforestry innovations with special reference to India- a review. Agricultural Situation in India, 74(4): 11-18.

42.Quli, S.M.S., Islam, M.A. and Singh, P.K. (2017). Mitigating livelihood crisis through agroforestry interventions in rural India. Jharkhand Journal of Development and Management Studies, 15(1):
7159-7178.

43.Reddy, Y.V.R. and Korwar, G.R. (1985). A comparative evaluation in agriculture and silvopastoral systems in drylands. Agricultural Situation in India, 40(8): 705-708.

44.Reisner, Y., de Filippi, R., Herzog F., Palma J. (2007). Target regions for silvoarable agroforestry in Europe. Ecological Engineering, 29(4): 401-418.

45.Roy, M.M. (1999). Silvopastoral systems. Agroforestry Today, 11(1-2): 24-26.

46.Schaffer, C., Eksvärd, K. and Björklund, J. 2019. Can Agroforestry Grow beyond Its Niche and Contribute to a Transition towards Sustainable Agriculture in Sweden? Sustainability, 11(13): 1-14.

47.Snedecor, G. and Cochran, W.G. (1967). Statistical Methods. lowa State Univ. Press, Ames, lowa, USA, 17-36.

48.Sood, K.K. (2006). The influence of household economics and farming aspects on adoption to traditional agroforestry in Western Himalaya. Mountain Research and Development. 26(2):124-130.

49.Swinkels, R. and Scherr, S.J. (1991). Economic Analysis of Agroforestry systems: An Annotated Bibliography. ICRAF, Nairobi.

50.Thomas, T.H. (1990). Agroforestry: does it pay? Outlook in Agriculture, 19(3): 161- 170.

51.Yadav, A., Gendley, M.K., Sahu, J., Patel, P.K., Chandraker, K. and Dubey, A. (2019). Silvopastoral system: A prototype of livestock agroforestry. The Pharma Innovation Journal, 8(2): 76-82. 